УДК 792.82(477):[7.094:792.54

DOI: 10.31866/2616-7646.4.2.2021.249293

\title{
ІНТЕРПРЕТАЦІЯ ОПЕРНИХ ТВОРІВ НА УКРАЇНСЬКІЙ БАЛЕТНІЙ СЦЕНІ
}

\author{
Хоцяновська Людмила Францівна, \\ заслужена артистка України, доцентка, \\ Київський національний університет культури і мистецтв, \\ Київ, Україна, \\ https://orcid.org/0000-0001-8451-3185, \\ khotsyadukr.net \\ Перова Ганна Олексіївна, \\ заслужена артистка України, доцентка, \\ Київський національний університет культури і мистецтв, \\ Київ, Україна, \\ https://orcid.org/0000-0003-0722-9775, \\ mukoseevaQukr.net
}

\begin{abstract}
Мета статті - виявити особливості балетмейстерських інтерпретацій оперних вистав на українській балетній сцені. Методологія. Для проведення дослідження застосовано комплекс загальних (аналіз та синтез, індукція та дедукція, порівняння) і спеціальних (мистецтвознавчий аналіз) наукових методів. Наукова новизна. Вперше проаналізовано балетні інтерпретації оперних вистав в Україні. Висновки. При інтерпретації оперних творів на балетній сцені відбувається зміщення змістовних акцентів у залежності від балетмейстерського задуму. Хореографічна інтерпретація не передбачає розкриття музично-вокальної концепції твору, балетмейстери вдаються до купюр музичної партитури у відповідності до розробленого сценарно-композиційного плану. Часто єдиним мірилом композиційної структури партитури виступають музичний та естетичний смаки балетмейстера. Основою для створення балетних вистав переважно стають опери минулих століть, відбувається своєрідна актуалізація змісту твору в іншій історико-культурній епосі. Серед таких творів на українській сцені «Кармен-сюїта» Ж. Бізе - Р. Щедріна (перенесена вистава А. Алонсо), «Весілля Фігаро» В. А. Моцарта у постановці В. Яременка, «Кармен. TV» у постановці Р. Поклітару. Зустрічаємо і свідому відмову балетмейстерів від використання оперних партитур при реалізації тем, що мають у глядачів стійкі асоціації з операми («Дама з камеліями» у постановці А. Рехвіашвілі, «Пікова дама» у постановці Р. Поклітару). Загалом оперні вистави є вагомим джерелом для балетних інтерпретацій.
\end{abstract}

Ключові слова: балетна інтерпретація; інтерпретація опери; хореографічне мистеизтво; балет. 


\section{ИНТЕРПРЕТАЦИЯ ОПЕРНЫХ ПРОИЗВЕДЕНИЙ НА УКРАИНСКОЙ БАЛЕТНОЙ СЦЕНЕ}

\author{
Хоцяновская Людмила Францевна, \\ заслуженная артистка Украины, доцент, \\ Киевский национальный университет \\ культуры и искусств, \\ Киев, Украина, \\ https://orcid.org/0000-0001-8451-3185, \\ khotsyaQukr.net \\ Перова Анна Алексеевна, \\ заслуженная артистка Украины, \\ доцент, \\ Киевский национальный университет \\ культуры и искусств, \\ Киев, Украина, \\ https://orcid.org/0000-0003-0722-9775, \\ mukoseevaQukr.net
}

Цель статьи - определить особенности балетмейстерских интерпретаций оперных представлений на украинской балетной сцене. Методология. Для проведения исследования применен комплекс общих (анализ и синтез, индукция и дедукция, сравнение) и специальных (искусствоведческий анализ) научных методов. Научная новизна. Впервые проанализированы балетные интерпретации оперных представлений в Украине. Выводы. При интерпретации оперных произведений на балетной сцене происходит смещение содержательных акцентов в зависимости от балетмейстерского замысла. Хореографическая интерпретация не предусматривает раскрытие музыкально-вокальной концепции произведения, балетмейстеры прибегают к купюрам музыкальной партитуры в соответствии с разработанным сценарно-композиционным планом. Часто единственным мерилом композиционной структуры партитуры выступают музыкальный и эстетический вкусы балетмейстера. Основой для создания балетных представлений преимущественно становятся оперы прошлых веков, происходит своеобразная актуализация содержания произведения

\section{INTERPRETATION OF OPERA WORKS ON THE UKRAINIAN BALLET STAGE}

\author{
Liudmyla Khotsianovska, \\ Honored Artist of Ukraine, \\ Associate Professor, \\ Kyiv National University \\ of Culture and Arts, \\ Kyiv, Ukraine, \\ https://orcid.org/0000-0001-8451-3185, \\ khotsyaQukr.net \\ Hanna Perova, \\ Honored Artist of Ukraine, \\ Associate Professor, \\ Kyiv National University of Culture and Arts, \\ Kyiv, Ukraine, \\ https://orcid.org/0000-0003-0722-9775, \\ mukoseevalaukr.net
}

The purpose of the article is to reveal the peculiarities of choreographed interpretations of opera performances on the Ukrainian ballet stage. Research methodology. A set of general (analysis and synthesis, induction and deduction, comparison) and special (art analysis) scientific methods was used to conduct the research. Scientific novelty. Ballet interpretations of opera performances in Ukraine were analyzed for the first time. Conclusions. When interpreting operas on the ballet stage, there is a shift of meaningful accents depending on the choreographer's plan. Choreographic interpretation does not involve the disclosure of the musical-vocal concept of the work. Choreographers resort to notes of musical score in accordance with the developed script-compositional plan. Often the only measure of the compositional structure of the score is the musical and aesthetic taste of the choreographer. The basis for the creation of ballet performances are mainly operas of past centuries, there is a kind of actualization of the work content in another historical and cultural era. Among such works on the Ukrainian stage 'Carmen Suite' by J. Bizet - R. Shchedrin (postponed play by A. Alonso), 'The Wedding of Figaro' by V. A. Mozart in the production of V. Yaremenko, 'Carmen. 
в другой историко-культурной эпохе. Среди таких произведений на украинской сцене «Кармен-сюита» Ж. Бизе - Р. Щедрина (перенесенный спектакль А. Алонсо), «Свадьба Фигаро» В. А. Моцарта в постановке В. Яременко, «Кармен. TV» в постановке Р. Поклитару. Встречаем и сознательный отказ балетмейстеров от использования оперных партитур при реализации тем, имеющих у зрителей устойчивые ассоциации с операми («Дама с камелиями» в постановке А. Рехвиашвили, «Пиковая дама» в постановке Р. Поклитару). В целом оперные спектакли являются значимым источником для балетных интерпретаций.

Ключевые слова: балетная интерпретация; интерпретация оперы; хореографическое искусство; балет.
TV' directed by R. Poclitaru. We also meet the choreographers' conscious refusal to use opera scores in the realization of themes that have strong associations with operas ('Lady with Camellias' directed by A. Rekhviashvili, 'Queen of Spades' directed by R. Poklitaru). In general, opera performances are an important source for ballet interpretations.

Key words: ballet interpretation; interpretation of the opera; choreographic art; ballet.

Актуальність теми дослідження. Від моменту оформлення балетної вистави як самостійного сценічного дійства із середини XVI століття (до того танцювальні фрагменти, дивертисменти не мали самостійного значення, часто були складниками оперних вистав) і до сьогодні не втрачає актуальності проблема пошуку джерел для постановки балетів. Досить часто упродовж всієї історії розвитку балетного театру основою вистав ставали міфологічні сюжети, літературні твори. У XX ст. діапазон тем для втілення на балетній сцені значно розширився, увібравши не лише літературні, а й кінематографічні твори, образотворче мистецтво, історичні події, побутові ситуації, будь-які явища природи, людські емоції та ін.

Серед помітних «натхненників» балетмейстерів у XX та XXI століттях можна назвати оперні вистави (зважаючи на їх синтетичність, говоримо саме про оперні вистави, попри те, що у більшості з них в основу покладено літературний твір). Але, враховуючи тісний зв'язок хореографічного мистецтва з музикою, фрагменти оперних партитур використовуються для створення партитур балетних. Тому вважаємо, що саме опера, а не літературний твір, покладений в його основу, стають поштовхом для балетної інтерпретації. Звернення уваги науковців до цього явища $є$ перспективним в аспекті виявлення специфіки хореографічної інтерпретації оперних творів.

Аналіз останніх досліджень та публікацій. Проблема першооснови балетної вистави розроблялася балетознавцями у різних ракурсах. Хореографічним інтерпретаціям літературних творів присвячено праці Н. Аркіної (Аркина, 1987), М. Загайкевич (1978), В. Красовської (Красовская, 2005), Б. Сметаніної (Сметанина, 2007) та ін., специфіці інтерпретації різножанрової музики - В. Ванслова (2007), Ю. Абдокова (2009) та ін. Дослідження О. Гаснікової (Гасникова, 2020, 2021) спеціально присвячені пластичним інтерпретаціям опери в балетний спектакль у практиці західноєвропейських та російських балетмейстерів. Але до кола на- 
укових інтересів балетознавців не потрапляли проблеми інтерпретації оперних творів засобами хореографічного мистецтва на українській балетній сцені.

Мета статті - виявити особливості балетмейстерських інтерпретацій оперних вистав на українській балетній сцені.

Виклад основного матеріалу. Витоки сучасної тенденції звернення балетмейстерів до оперної вистави як першооснови балетної слід шукати у XVIII ст., коли вони почали використовувати музику оперних партитур, що спровокувало появу балетів-двійників. Серед таких балетів «Облога Цитери» К. Глюка у постановці Г. Анджоліні (1762), «Земіра та Азор» А. Гретрі у постановці Ф. Мореллі (1783), «Орфей та Еврідіка» К. Глюка у постановці І. Вальберха (1808), «Севільський цирульник» Дж. Пазієлло в постановці Л. Дюпора (1809), «Мельник» М. Соколовського у постановці А. Огюста (1810) та ін. (Гасникова, 2020, с. 104-105).

На початку XX ст. балетмейстери продовжили звернення до опер як основи вже не для балетів-двійників, а для повноцінних хореографічних інтерпретацій. Серед таких вистав - опера «Золотий півник» М. Римського-Корсакова в хореографії М. Фокіна (1914), реалізована завдяки С. Дягілєву у проєкти «Російський балет Сергія Дягілєва». Також відомим $є$ втілення Л. Мясіна балету «Опівнічне сонце» на музику з опери М. Римського-Корсакова «Снігуронька» (1915).

«Трансформацією опери в балетну виставу» називає балетну інтерпретацію оперного твору О. Гаснікова (Гасникова, 2021, с. 28), аналізуючи балет «Чарівна флейта» за однойменною оперою В. А. Моцарта у постановці М. Бежара та А. Петрова.

Розглядаючи проблему інтерпретації в балеті, О. Кирпиченкова досить стримано ставиться до постмодерністського сприйняття музичної партитури як тексту, з яким можна поводитись як завгодно: «Одні дотримуються ідеї максимально образного зближення музики та хореографії, інші ставляться до музичної партитури в руслі постмодернізму, тобто сприймають її як текст, який можна піддати будьяким метаморфозам. Останній підхід загрожує зміщенням сенсових акцентів, коли хореографічна візуалізація партитури не збігається зі змістом музичного тексту або навіть суперечить йому за образно-художнім наповненням» (Кирпиченкова, 2017, с. 48). Одночасно вважаємо, що при використанні оперної партитури для постановки балетної вистави не можна обійтися без перестановок фрагментів, купюр, часто - компіляції з іншими музичними творами. Хореограф має право змінювати програму вистави, місце та час дії, вводити нових персонажів, втручатися в суть конфлікту, одночасно може зберегти основну сценарну канву, але змістити режисерські, акторські акценти, наділити героїв іншими рисами та ін.

Найяскравішим прикладом звернення балетмейстера до оперної вистави стала реалізація балету «Кармен» (1967) на музику Ж. Бізе в транскрипції Р. Щедріна у постановці кубинського хореографа Альберто Алонсо спеціально для М. Плісецької. Слід зазначити, що і до того, і після того до партитури Ж. Бізе зверталися різні хореографи (Ролан Петі, Джон Кренко, Антоніо Гадес, Матс Ек, Метью Борн та ін.), але постановка А. Алонсо залишається однією з найпопулярніших на багатьох сценах світу упродовж понад п’ятдесяти років. В Одеський театр опери та балету «Кармен-сюїту» зі сцени Большого театру СРСР в Москві переніс Азарій Плісецький 1973 року (Станішевський, 2003, с. 2019). Партію Кармен на сцені Київського державного театру опери та балету ім. Т. Г. Шевченка блискуче виконували Валентина Калиновська, Ганна Кушнірова, Олена Філіп'єва та ін., на хар- 
ківській сцені - Світлана Коливанова. Сьогодні ця вистава входить до репертуару українських оперно-балетних театрів.

25 жовтня 2006 року в Києві відбулася прем’єра вистави «Кармен. TV» на музику Ж. Бізе у постановці Р. Поклітару. Фактично цей балет став початком діяльності «Київ модерн-балету» - колективу, що за п’ятнадцять років свого існування набув широкої популярності в Україні та за її межами. За цю постановку Р. Поклітару отримав престижну премію «Київська пектораль» у номінаціях «Краща вистава року» та «Краща робота балетмейстера». Т. Поліщук акцентувала на вагомості музики, що надихнула балетмейстера на створення новітнього рішення: «Завдяки новаторській хореографії сценічне життя персонажів наповнилося зворушливими сучасними інтонаціями, зберігши при цьому шарм Іспанії XIX століття, а геніальна музика опери “Кармен” дала можливість балетмейстерові створити абсолютно новий спектакль, не змінивши дух Жоржа Бізе» (Поліщук, 2016).

Р. Поклітару вдається до переробки сюжету, що для балетмейстера стало традиційним і у подальших постановках. Мікаела у виставі не виступає нареченою Хозе, як це трактується в опері, але стає фактично рушійною. силою балетної дії. Балетмейстер, за його зізнанням, вкладає до вуст Мікаели такі слова: «Коли поруч нікого немає, любов переповнює мене і змушує бачити, бажати, вбивати неіснуючих персонажів ніким не знятих фільмів. Мерехтіння екрана спілкується зі мною мовою пристрасті. Я самотня?.. Нi! (Кармен. TV, 2006). Саме цей образ пояснює, чому у назві балету присутні літери TV, чому його жанр визначено як «балет на дві серії».

Але це було не перше звернення Р. Поклітару до теми Кармен: 2001 року він уже втілював «Кармен» у Національному театрі опери та балету Республіки Молдова (м. Кишинів), а також 2002 року в Україні на сцені Одеського коледжу мистецтв ім. Костянтина Данькевича.

2006 року на сцені Національної опери України балетмейстером Віктором Яременком поставлений комедійний балет «Весілля Фігаро» за однойменною оперою В. А. Моцарта. Лібрето створене В. Яременком та Ю. Станішевським, музичну редакцію оперної партитури здійснив Олексій Баклан, відомий диригент-постановник, який майстерно веде балетні вистави.

Ю. Бентя називає виставу «пародією на академічний балет», визнає їі оригінальність та успіх у глядачів. Постановники залишили від опери увертюру, двохактну форму, основну сюжетну лінію та головних персонажів: граф, графиня, Сюзанна, Фігаро, ключниця Марцеліна, доктор Бартоло, вчитель музики дон Базиліо. Слід зауважити, що партитуру О. Баклан створив із тридцяти шести ранніх творів Моцарта.

Балетмейстер поставив комічну виставу засобами неокласичного танцю. Але подекуди В. Яременко вводить елементи вільної пластики, побутові рухи, які рецензентка Ю. Бентя (2006) називає «чимось середнім між балетом і спортивною гімнастикою».

На українській балетній сцені зустрічаються і парадоксальні ситуації, коли балетмейстери відмовляються від оперної партитури, хоча усвідомлюють, що глядач очікує саме цього. У червні 2014 року на сцені Національної опери України світ рампи побачив балет «Дама з камеліями» у постановці Аніко Рехвіашвілі. Балетмейстери вже неодноразово зверталися до балетної інтерпретації твору О. Дюма. Серед найвідоміших є такі, хто дистанціювалися від музики Дж. Верді («Маргарита 
і Арман» Фредеріка Аштона на музику Ференца Ліста, «Дама $з$ камеліями» Джона Ноймайєра на музику Фредеріка Шопена та ін.), або використовували їі (постановка Дмитра Брянцева у Московському академічному театрі імені К. Станіславського та В. Немировича-Данченка; інтерпретація Олександра Полубенцева у Татарському академічному державному театрі опери та балету ім. М. Джаліля).

«Постановка нова у повному розумінні цього слова, - розповідає Аніко Рехвіашвілі. - Це новий підхід до музичної концепції. Ми не адаптуємо музичний матеріал до опери “Травіата” Дж. Верді, хоча це очікувано. Не використовуємо твори одного автора, наприклад, Шопена чи Ліста, як це робили інші постановники, які до нас інтерпретували роман О. Дюма. В нашій виставі звучить музика Л. Бетховена, І. Брамса, І. Пахельбеля, Г. Форе, Е. Елгара, І. Стравінського» (Апанасенко, 2014). Розробник музичної партитури О. Баклан вважає, що відмова від музики опери Дж. Верді дозволяє створити оригінальну виставу, а не «протанцьовану оперу», хоча визнає, що композиція опери «Травіата» досконала, і навряд чи можна створити щось більш вдале, і тема Марі Деплюссі завжди буде асоціюватися з оперою Верді.

2021 року Р. Поклітару виніс на суд глядачів двохактну балетну виставу «Пікова дама», яка асоціюється з однойменною оперою П. Чайковського. Початково у постановника був задум реалізувати виставу саме з оперною музикою П. Чайковського. «Та мені не вдалося здійснити постановку балету з використанням оперної партитури, оскільки під час створення сценарного плану та музичного монтажу випадково зрозумів, що мені “заважає” текст. Тому від цієї ідеї довелося відмовитися, бо я побачив, як хореографія перетворюється на банальний танцювальний підрядник, позбавлений алегоричності та емоційної незалежності. Після кількох невдалих спроб упоратися із цією проблемою все ж вирішив залишити ідею створення балетно-оперної “Пікової дами” на тривалий час», - пояснює Р. Поклітару в інтерв’ю відомому театральному рецензенту О. Вергелісу (Вергеліс, 2021). І стає зрозумілим, що балетмейстер прагнув створити самоцінний твір безвідносно до опери П. Чайковського. У підсумку балет було поставлено на музику двох частин Другої симфонії П. Чайковського (перший акт) та Шостої симфонії П. Чайковського (другий акт).

Висновки. При інтерпретації оперних творів на балетній сцені відбувається зміщення змістовних акцентів у залежності від балетмейстерського задуму. Хореографічна інтерпретація не передбачає розкриття музично-вокальної концепції твору, балетмейстери вдаються до купюр музичної партитури у відповідності до розробленого сценарно-композиційного плану. Часто єдиним мірилом композиційної структури партитури виступають музичний та естетичний смаки балетмейстера.

Основою для створення балетних вистав переважно стають опери минулих століть, відбувається своєрідна актуалізація змісту твору в іншій історико-культурній епосі. Серед таких творів на українській сцені «Кармен-сюїта» Ж. Бізе Р. Щедріна (перенесена вистава А. Алонсо), «Весілля Фігаро» В. А. Моцарта у постановці В. Яременка, «Кармен. TV» у постановці Р. Поклітару. Зустрічаємо і свідому відмову балетмейстерів від використання оперних партитур при реалізації тем, що мають у глядачів стійкі асоціації з операми («Дама з камеліями» у постановці А. Рехвіашвілі, «Пікова дама» у постановці Р. Поклітару). Загалом оперні вистави $€$ вагомим джерелом для балетних інтерпретацій. 


\section{СПИСОК ПОСИЛАНЬ}

Абдоков, Ю. Б. (2009). Музыкальная поэтика хореографии: Пластическая интерпретация музыки в хореографическом искусстве: Взгляд композитора. ГИТИС.

Апанасенко, В. (2014). Спокута коханням. Національна опера України. https://opera.com.ua/ performance/dama-z-kameliyami

Аркина, Н. Е. (1987). Балет и литература. Знание.

Бентя, Ю. (2006, 22 березня). Моцарт через скакалочку: У Національному театрі опери і балету відбулася прем’єра комічного балету на музику Моцарта «Весілля Фігаро». Голос України. http://www.golos.com.ua/article/218829

Ванслов, В. В. (2007). О музыке и о балете. Памятники исторической мысли.

Вергеліс, О. (2021, 14 вересня). Карти - на стіл! Раду Поклітару презентує прем’єру балету «Пікова дама» на музику Петра Чайковського. Театрально-концертний Київ. https:// www.tkk.media/karty-na-stil/

Гасникова, О. В. (2020). К вопросу о трансформации оперы в балетный спектакль (на примере творчества русских и западноевропейских хореографов). Художественное образование и наука, 1(22), 103-113. https://doi.org/10.34684/hon.202001013

Гасникова, О. В. (2021). Пластическая интерпретация оперы в балетный спектакль: балет «Волшебная флейта» на музыку В. А. Моцарта в постановке А. Б. Петрова в театре «Кремлевский балет». Вестник Академии Русского балета им. А. Я. Вагановой, 1(72), 26-42.

Загайкевич, М. П. (1978). Драматургія балету. Наукова думка.

Кармен. TV. (2006). Kyiv Modern Ballet. https://kyivmodernballet.com/theater/repertoire/22

Кирпиченкова, О. В. (2017). Термин «интерпретация» в теории балета и критерий художественной значимости хореографической интерпретации. Обсерватория культуры, 14(1), 46-53. https://doi.org/10.25281/2072-3156-2017-14-1-46-53

Красовская, В. (2005). Балет сквозь литературу. Академия Русского балета им. А. Я. Вагановой.

Поліщук, Т. (2016, 18 жовтня). Початок історії - «Кармен. TV»: «Київ модерн-балет» святкує 10-річчя заснування колективу. День. https://day.kyiv.ua/uk/article/kultura/pochatokistoriyi-karmentv

Сметанина, Б. О. (2007). Интерпретация литературных образов в балете: эпизоды из творческого опыта Бориса Эйфмана. Известия Российского государственного педагогического университета им. А. И. Герцена, 8(27), 77-79.

\section{REFERENCES}

Abdokov, Yu. (2009). Muzykal'naya Poetika Khoreografii: Plasticheskaya Interpretatsiya Muzyki v Khoreograficheskom Iskusstve: Vzglyad Kompozitora [Musical Poetics of Choreography: Plastic Interpretation of Music in Choreographic Art: The Composer's View]. GITIS [in Russian].

Apanasenko, V. (2014). Spokuta Kokhanniam [Atonement with Love]. National Opera of Ukraine. https://opera.com.ua/performance/dama-z-kameliyami [in Ukrainian].

Arkina, N. (1987). Balet i Literatura [Ballet and Literature]. Znanie [in Russian].

Bentia, Yu. (2006, March 22). Motsart cherez skakalochku: U Natsionalnomu Teatri Opery i Baletu Vidbulasia Premiera Komichnoho Baletu na muzyku Motsarta "Vesillia Fiharo" [Mozart through a Skipping Rope: The National Opera and Ballet Theater Hosted the Premiere of Mozart's Comic Ballet "The Wedding of Figaro"]. Holos Ukrainy. http://www.golos.com.ua/ article/218829 [in Ukrainian]. 
Carmen. TV. (2006). Kyiv Modern Ballet. https://kyivmodernballet.com/theater/repertoire/22 [in Ukrainian].

Gasnikova, O. (2020). K Voprosu o Transformatsii Opery v Baletnyi Spektakl' (na Primere Tvorchestva Russkikh i Zapadnoevropeiskikh Khoreografov) [Transformation of an Opera Performance into a Ballet (by Russian and West European Choreographers)]. Khudozhestvennoe Obrazovanie i Nauka [Arts Education and Science], 1(22), 103-113. https://doi.org/10.34684/hon.202001013 [in Russian].

Gasnikova, O. (2021). Plasticheskaya Interpretatsiya Opery v Baletnyi Spektakl': Balet "Volshebnaya Fleita" na Muzyku V. A. Motsarta v Postanovke A. B. Petrova v Teatre "Kremlevskii Balet" [Plastic Interpretation of Opera in a Ballet Performance: Ballet "The Magic Flute" to the Music of V. A. Mozart Staged by A. B. Petrov at the Kremlin Ballet Theater]. Vestnik Akademii Russkogo Baleta im. A. Ya. Vaganovoi [Bulletin of Vaganova Ballet Academy], 1(72), 26-42 [in Russian].

Kirpichenkova, O. (2017). Termin "Interpretatsiya" v Teorii Baleta i Kriterii Khudozhestvennoi Znachimosti Khoreograficheskoi Interpretatsii [The Term of "Interpretation" in Ballet Theory and the Criterion of Artistic Value of Choreographic Interpretation]. Observatoriya Kul'tury [Observatory of Culture], 14(1), 46-53. https://doi.org/10.25281/2072-3156-201714-1-46-53 [in Russian].

Krasovskaya, V. (2005). Balet skvoz' Literaturu [Ballet through Literature]. Vaganova Ballet Academy [in Russian].

Polishchuk, T. (2016, October 18). Pochatok Istorii - "Karmen.TV": "Kyiv Modern-Balet" Sviatkuie 10-richchia Zasnuvannia Kolektyvu [The Beginning of the Story - "Carmen.TV": "Kyiv Modern Ballet" Celebrates the 10th Anniversary of the Band]. Den. https://day.kyiv.ua/uk/ article/kultura/pochatok-istoriyi-karmentv [in Ukrainian].

Smetanina, B. (2007). Interpretatsiya Literaturnykh Obrazov v Balete: Epizody iz Tvorcheskogo Opyta Borisa Eifmana [Interpretation of Literary Images in Ballet: Episodes from the Creative Experience of Boris Eifman]. Izvestiya Rossiiskogo Gosudarstvennogo Pedagogicheskogo Universiteta im. A. I. Gertsena [Izvestia: Herzen University Journal of Humanities \& Sciences], 8(27), 77-79 [in Russian].

Vanslov, V. (2007). O Muzyke i o Balete [About Music and Ballet]. Pamyatniki istoricheskoi mysli [in Russian].

Verhelis, O. (2021, September 14). Karty - na Stil! Radu Poklitaru Prezentuie Premieru Baletu "Pikova dama" na Muzyku Petra Chaikovskoho [Cards - on the Table! Radu Poklitaru Presents the Premiere of the Ballet "The Queen of Spades" to the Music of Peter Tchaikovsky]. Teatralno-Kontsertnyi Kyiv. https://www.tkk.media/karty-na-stil/ [in Ukrainian].

Zahaikevych, M. (1978). Dramaturhiia Baletu [Ballet Drama]. Naukova dumka [in Ukrainian]. 